\title{
Anaplastic Astrocytoma, IDH-Wildtype
}

National Cancer Institute

\section{Source}

National Cancer Institute. Anaplastic Astrocytoma, IDH-Wildtype. NCI Thesaurus. Code C129291.

Anaplastic astrocytoma lacking mutations in IDH1 or IDH2 genes. 